\title{
ANALISIS FAKTOR-FAKTOR YANG MEMPENGARUHI KINERJA KEUANGAN PERUSAHAAN
}

\author{
Imanuel Parluhutan Mangasi Nainggolan \\ Fakultas Ekonomi dan Ilmu Sosial Universitas Bakrie \\ Email: imanuel.nainggolan@gmail.com \\ Monica Weni Pratiwi \\ Fakultas Ekonomi dan Ilmu Sosial Universitas Bakrie \\ Email: monica.wenipratiwi@bakrie.ac.id
}

\begin{abstract}
Abstrak
Penelitian ini bertujuan untuk menganalisis faktor-faktor yang memengaruhi kinerja keuangan perusahaan. Faktor-faktor tersebut diproksikan menjadi konservatisme akuntansi, konvergensi International Financial Reporting Standard, dan struktur modal. Sampel yang digunakan dalam penelitian ini adalah perusahaan manufaktur yang terdaftar di Bursa Efek Indonesia dari tahun 2011 sampai dengan 2013 sebanyak 153 sampel. Dalam penelitian ini metode analisis data yang digunakan adalah pendekatan kuantitatif dengan menggunakan regresi berganda. Berdasarkan penelitian yang telah dilakukan pada perusahaan manufaktur terdaftar di Bursa Efek Indonesia, dapat disimpulkan bahwa konservatisme akuntansi dan struktur modal berpengaruh terhadap kinerja keuangan sedangkan konvergensi International Financial Reporting Standard yang diproksikan dengan manajemen laba tidak berpengaruh terhadap kinerja keuangan.
\end{abstract}

Kata Kunci: Kinerja Keuangan, Konservatisme Akuntansi, Konvergensi International Financial Reporing Standard, Struktur Modal.

\begin{abstract}
This study aimed to analyze the factors that affect the company's financial performance. These factors proxy into accounting conservatism, the convergence of International Financial Reporting Standards, and capital structure. The sample used in this research is manufacturing companies listed in Indonesia Stock Exchange from 2011 to 2013 as many 153 sample. In this study, data analysis method used is quantitative approach using multiple regression. Based on research that has been conducted on manufacturing companies listed in Indonesia Stock Exchange, it can be concluded that accounting conservatism and capital structure affect the financial performance whereas convergence of International Financial Reporting Standard proxy by earnings management has no effect on the financial performance.
\end{abstract}

Keywords: Financial Performance, Accounting Conservatism, The Convergence Of International Financial Reporting Standard, Capital Structure. 


\section{PENDAHULUAN}

Perusahaan manufaktur merupakan industri yang dalam kegiatannya mengandalkan modal dari investor, oleh karena itulah perusahaan manufaktur harus dapat menjaga kesehatan keuangan atau likuiditasnya. Keadaan tersebut menuntut kebutuhan dana yang cukup bagi perusahaan manufaktur untuk bertahan dan bersaing. Salah satu cara yang diambil perusahaan untuk memenuhi kebutuhan dana guna mengembangkan agar tetap dapat bersaing adalah penjualan saham perusahaan kepada masyarakat melalui pasar modal. Pasar modal memiliki peran yang sangat penting dalam meningkatkan pertumbuhan ekonomi suatu negara karena memiliki fungsi ekonomi dan fungsi keuangan (Husnan, 2003).

Para pelaku bisnis dan pemerintah membutuhkan informasi tentang kondisi dan kinerja keuangan perusahaan untuk pengambilan keputusan ekonomi. Analisis laporan keuangan sangat dibutuhkan untuk memahami informasi laporan keuangan. Analisis kinerja keuangan merupakan alternatif untuk menguji apakah informasi keuangan bermanfaat untuk melakukan klasifikasi atau prediksi terhadap harga saham. Pada tahun 2008 standar akuntansi yang ada di Indonesia yaitu PSAK telah dikonvergensikan ke International Financial Reporting Standard (IFRS). IFRS merupakan wujud penolakan dan kritik terhadap prinsip konservatisme akuntansi karena prinsip fair value lebih menekankan pada relevansi. Oleh karena itu, IFRS bertujuan untuk membentuk laporan keuangan yang berdasarkan fakta saat ini bukan peristiwa masa lalu. Dengan munculnya IFRS diharapkan kinerja keuangan yang tercermin dalam laporan keuangan perusahaan dapat lebih dipercaya sehingga bisa dijadikan dasar pengambilan keputusan baik bagi pengguna internal maupun eksternal.

Kinerja keuangan perusahaan merupakan penentuan ukuran-ukuran yang dapat digunakan untuk menjadi tolak ukur keberhasilan perusahaan menghasilkan laba (Sucipto, 2003). Kinerja keuangan yang baik dapat membantu manajemen dalam pencapaian tujuan perusahaan. Semakin tinggi kinerja perusahaan, semakin tinggi pula nilai perusahaan di mata investor. Menurut Winarni dan Sugiarso (2005), kinerja dapat diartikan sebagai prestasi yang dicapai oleh perusahaan dalam suatu periode tertentu yang mencerminkan tingkat kesehatan perusahaan.

Konservatisme akuntansi merupakan salah satu teori yang muncul dengan tujuan untuk membuat laporan keuangan yang baik dan dapat dipertanggungjawabkan. Konservatisme juga berhubungan erat dengan nilai aset perusahaan karena termasuk di dalamnya penundaan pengakuan pendapatan yang berujung pada turunnya nilai laba ditahan. Lo (2005) mendeskripsikan konsep konservatisme sebagai konsep pesimistik dalam akuntansi. Prinsip konservatisme dalam akuntansi itu sendiri merupakan prinsip dalam laporan keuangan yang dimaksudkan untuk mengakui dan mengukur aktiva dan laba yang dilakukan dengan penuh kehati-hatian. Oleh karena aktivitas ekonomi dan bisnis yang penuh ketidakpastian. Dengan kata lain mengakui beban dan kewajiban sesegera mungkin meskipun ada ketidakpastian di dalamnya dan mengakui pendapatan dan aktiva ketika sudah yakin akan diterima.

Lafond dan Roychowdury (2007) menyatakan bahwa konservatisme akuntansi meliputi penggunaan standar yang lebih tepat untuk mengakui bad news sebagai kerugian dan untuk mengakui good news sebagai keuntungan dan memfasilitasi kontrak yang efisien antara manajemen dan shareholder. Sampai saat ini prinsip konservatisme akuntansi masih dianggap sebagai prinsip yang kontroversial. Hal ini dikarenakan beberapa kritikus seperti Monahan dalam Wilopo (2002) menyatakan bahwa semakin konservatif akuntansi, maka nilai ekuitas yang dihasilkan akan semakin bias. Akan tetapi dari pihak pendukung seperti 
Ohlson (1995) dan Watts (1993) dalam Fala (2007) membuktikan dalam penelitiannya bahwa laba dan aktiva yang dihitung secara konservatif dapat meningkatkan kualitas laba sehingga dapat digunakan untuk menilai perusahaan.

Givoly dan Hayn (2000) mengukur konservatisme akuntansi dengan melihat kecenderungan dari akumulasi akrual selama beberapa tahun. Akrual yang dimaksud adalah perbedaan antara laba bersih sebelum depresiasi atau amortisasi dan arus kas operasi. Apabila terjadi akrual negatif (laba bersih lebih kecil dari kegiatan arus kas operasi) yang konsisten selama beberapa tahun, maka merupakan indikasi diterapkannya konservatisme. Semakin besar akrual negatif yang diperoleh maka semakin konservatif akuntansi yang diterapkan. Hal ini dilandasi dengan teori bahwa konservatisme menunda pengakuan pendapatan dan mempercepat pengakuan biaya.

Selain konservatisme akuntansi, salah satu tantangan perusahaan dalam upayanya untuk meningkatkan kinerja keuangan ialah adanya standar internasional baru untuk laporan keuangan. International Financial Reporting Standards (IFRS) merupakan standar akuntansi internasional yang diterbitkan oleh International Accounting Standard Boards (IASB). IFRS telah diadopsi oleh berbagai negara dengan tingkat implementasi yang berbeda beda.

Indonesia memilih IFRS sebagai referensi dalam sistem akuntansinya. Program konvergensi IFRS di Indonesia dimulai tahun 2002, yaitu mulai dengan adanya harmonisasi antara PSAK dan International Accounting Standards (IAS) melalui revisi pada PSAK 24, PSAK 16, PSAK 30, dan munculnya standar akuntansi baru mengenai agrikultur. Pada akhir tahun 2003, lima puluh sembilan PSAK dan empat Interpretasi Standar Akuntansi Keuangan (ISAK) telah dinyatakan secara efektif digunakan sesuai dengan IAS. Revisi-revisi terhadap PSAK terus dilakukan dari tahun 2004 hingga tahun 2008 untuk meningkatkan kualitas dari Standar Akuntansi Keuangan (SAK) Indonesia. Hingga akhir tahun 2008, DSAK IAI telah mengeluarkan enam puluh dua PSAK yang terdiri dari lima puluh lima PSAK untuk transaksi konvensional dan tujuh PSAK untuk transaksi syariah, delapan ISAK, dan tiga technical bulletins (IAS, 2011).

DSAK (2008) menyatakan bahwa perbedaan-perbedaan mendasar antara PSAK dan IFRS akan hilang secara bertahap mulai tahun 2008 dan pengadopsian IFRS akan berlaku secara penuh pada tahun 2012. Proses tersebut akan membawa perubahan besar dalam praktik pelaporan keuangan di Indonesia yaitu menerapkan akuntansi nilai wajar untuk menggantikan akuntansi nilai historis. Perubahan tersebut disebabkan oleh beberapa standar IFRS maupun IAS telah menggunakan dasar pengukuran nilai wajar.

Penggunaan standar akuntansi internasional memiliki beberapa manfaat. Ashbaugh dan Pincus (2001) menyatakan bahwa keakuratan analisis dari para analis keuangan meningkat setelah perusahaan mengadopsi IFRS. Meningkatnya keakuratan analisis dari para analis keuangan tersebut disebabkan karena standar akuntansi internasional mensyaratkan pengungkapan (disclosure) yang lebih rinci daripada standar akuntansi lokal. Selain itu, penggunaan standar akuntansi internasional juga mempermudah perbandingan laporan keuangan antara perusahaan yang berdomisili di dua negara yang berbeda. Hal ini dimungkinkan karena kesamaan prinsip-prinsip dan aturan akuntansi yang digunakan kedua perusahaan sehingga mempermudah untuk melakukan perbandingan laporan keuangan.

Jermakowixz (2004) menyatakan bahwa penerapan IFRS berpengaruh pada pengukuran elemen dalam laporan keuangan seperti net income dan equity. Evans (2010) juga menyatakan bahwa 
penerapan IFRS berpengaruh signifikan terhadap shareholder equity, net income, dan liquidity. Beberapa penelitian sebelumnya membuktikan bahwa aplikasi dari penerapan IFRS memberikan dampak positif pada pelaporan dan kinerja keuangan dengan meningkatkan komparabilitas dan reliabilitas (Ashbaugh et al, 2001).

Standar keuangan yang baru tentunya akan mempengaruhi kinerja keuangan serta pelaporan keuangan perusahaan. Oleh karena itu Konvergensi IFRS dapat diproksikan dengan manajemen laba. Manajemen laba merupakan tindakan yang dilakukan oleh pihak manajemen dengan menaikkan atau menurunkan laba yang dilaporkan dari unit yang menjadi tanggung jawabnya yang tidak mempunyai hubungan dengan kenaikan atau penurunan profitabilitas dalam jangka panjang (Sulistyanto, 2008).

Selain konservatisme akuntansi dan konvergensi IFRS, struktur modal juga merupakan salah satu aspek yang berhubungan langsung dengan kinerja keuangan suatu perusahaan. Salah satu keputusan penting yang dihadapi manajer keuangan dalam kaitannya dengan operasi perusahaan adalah keputusan pendanaan. Perusahaan dapat didanai dengan utang dan ekuitas, utang (debt) yang dimaksud adalah utang untuk pendanaan perusahaan, tidak selalu sama sifatnya dengan kewajiban (liabilities) dan tidak sama dengan tagihan (payable). Utang menimbulkan beban bunga yang dapat menghemat pajak sehingga dapat mengurangi laba dan berujung pada berkurangnya pajak. Sedangkan dalam pendanaan menggunakan ekuitas, tidak ada beban yang terjadi sehingga tidak mengurangi pajak.

Jensen (1976) dalam Cao (2006) mengatakan bahwa penggunaan utang dalam struktur modal dapat mencegah pengeluaran perusahaan yang tidak penting dan memberikan dorongan kepada manajer untuk mengoperasikan perusahaan dengan lebih efisien. Hal tersebut memungkinkan untuk membuat kinerja perusahaan meningkat. Oleh karena itu dalam persaingan bisnis yang ketat, perusahaan harus memiliki keputusan pendanaan yang tepat, dimana perlu adanya peran manajer untuk menentukan struktur modal yang paling optimal. Struktur modal yang optimal dari perusahaan akan mampu meminimalkan biaya modal yang harus ditanggung oleh perusahaan sehingga perusahaan beroperasi dengan efisien.

Penelitian ini merupakan replikasi dari penelitian Fitriyani (2012) yang berjudul pengaruh manajemen laba terhadap kinerja keuangan perusahaa. Perbedaan dengan penelitian terdahulu adalah menambahkan struktur modal dan konservatisme akuntansi sebagai variabel independen. Struktur modal ditambahkan dalam penelitian ini untuk menguji dan melihat kecenderungan komposisi struktur modal perusahaan manufaktur di Indonesia yang optimal. Konservatisme ditambahkan untuk melihat tingkat konservatisme pada perusahaan manufaktur di Indonesia setelah diterapkannya IFRS. Konvergensi IFRS dalam penelitian ini diukur dengan menggunakan manajemen laba. Oleh karena itu, penelitian ini meinvestigasi secara empiris terhadap fenomena yang berkaitan dengan klaim yang menyatakan bahwa konservatisme akuntansi berpengaruh terhadap kinerja keuangan perusahaan, manajemen laba berpengaruh terhadap kinerja keuangan perusahaan, dan struktur modal berpengaruh terhadap kinerja keuangan perusahaan.

Penelitian ini bermanfaat pada pengembangan teori, terutama kajian akuntansi keuangan mengenai konservatisme akuntansi, manajemen laba, dan struktur modal terhadap kinerja perusahaan. Penelitian ini juga bermanfaat bagi calon investor sebagai acuan dalam menganalisis keputusan akuntansi yang dendak dilakukan. Manfaat lain yang dapat dilakukan dalam penelitian ini adalah dapat menjadi acuan penelitian sejenis dan pengembangan penelitian selanjutnya. 
HIPOTESIS PENELITIAN

Pengaruh Konservatisme Akuntansi dan Kinerja Keuangan

Watts (2003) mendefinisikan konservatisme sebagai tindakan manajemen untuk lebih mengantisipasi pengakuan profit dan lebih cepat dalam mengakui adanya kerugian. Lo (2005) menyatakan bahwa implikasi dari akuntansi konservatif pada perusahaan adalah penerapan secara konservatif standar akuntansi keuangan (SAK) yang tercermin dalam aktivitas operasional perusahaan di antaranya:

memperlambat pengakuan pendapatan, (2) mempercepat pengakuan biaya, (3) merendahkan penilaian aktiva, meninggikan penilaian utang. Hal tersebut akan menjadikan nilai aktiva bersih perusahaan menjadi lebih rendah.

Sampai saat ini prinsip konservatisme masih dianggap sebagai prinsip yang kontroversial. Terdapat banyak kritikan yang muncul namun banyak juga yang mendukung penerapan konservatisme ini. Kritikus seperti Monahan dan Wilopo (2002) menyatakan bahwa semakin konservatif akuntansi maka nilai buku ekuitas yang dilaporkan akan semakin bias. Namun pihak pendukung seperti Feltham dan Olson (1995) serta Watts (1993) membuktikan bahwa laba dan aktiva yang dihitung dengan akuntansi konservatif dapat meningkatkan kualitas laba sehingga bisa digunakan untuk menilai perusahaan.

Kiriyanto dan Kuspriyanto (2006) menyatakan bahwa pihak kontra menilai laporan keuangan yang disusun berdasarkan metode konservatif yang cenderung bias karena tidak mencerminkan kondisi perusahaan yang sesungguhnya. Fala (2007) menyatakan bahwa pihak yang mendukung konservatisme menyatakan bahwa penerapan akuntansi konservatif akan menghasilkan laba serta kinerja keuangan yang berkualitas karena prinsip ini mencegah perusahaan untuk membesarbesarkan laba dan membantu pengguna laporan keuangan dengan menyajikan laba yang tidak overstated. Selain itu Feltham dan Olson (1995) serta Watts (1993) membuktikan bahwa laba dan aktiva yang dihitung dengan akuntansi konservatif dapat meningkatkan kualitas laba sehingga bisa digunakan untuk menilai perusahaan. Berdasarkan penelitian sebelumnya, hipotesis yang ingin dikembangkan dalam penelitian ini adalah:

$\mathrm{H}_{1}$ : Konservatisme akuntansi berpengaruh terhadap kinerja keuangan.

\section{Pengaruh Manajemen Laba dan Kinerja Keuangan}

Manajemen laba yang menjadi proksi dari IFRS merupakan tindakan yang dilakukan oleh manajemen dengan menaikkan atau menurunkan laba yang dilaporkan dari unit yang menjadi tanggung jawabnya yang tidak mempunyai hubungan dengan kenaikan atau penurunan profitabilitas jangka panjang. Sulistyanto (2008) menyatakan bahwa perbedaan pemahaman terhadap manajemen laba mendorong semakin berkembangnya model empiris yang digunakan untuk mengidentifikasi aktivitas rekayasa manajerial ini. Secara umum ada 3 kelompok model empiris manajemen laba yang diklasifikasikan atas dasar basis pengukuran yang digunakan, yaitu: model berbasis akrual, model berbasis specific accruals, dan model distribution of earnings.

Sejauh ini hanya model berbasis aggregate accruals yang diterima secara umum sebagai model yang memberikan hasil paling kuat dalam mendeteksi manajemen laba. Model berbasis aggregate accruals yang digunakan adalah Modified Jones Model dapat dipisahkan menjadi 2, yaitu discretionary accruals dan non-discretionary accruals. Discretionary accruals merupakan komponen total accruals yang berasal dari rekayasa manajerial dengan memanfaatkan kebebasan dan fleksibilitas dalam menentukan nilai estimasi pada metode akuntansi. Misalnya, kebebasan dalam menentukan estimasi nilai residu dalam 
penyusutan aktiva tetap dan nilai persentase piutang tak tertagih. Sementara itu, non-discretionary accruals merupakan komponen total accruals yang diperoleh secara alami dari pencatatan akuntansi dengan mengikuti standar akuntansi yang diterima secara umum (Sulistyanto, 2008).

Dalam upayanya untuk meningkatkan kinerja keuangan perusahaan, manajemen seringkali melakukan manejemen laba dengan tujuan untuk memperlihatkan earnings power perusahaan agar membentuk laporan keuangan serta rasio kinerja keuangan yang baik sehingga menarik minat investasi para calon investor karena meningkatnya harga saham (Dharmasetya dan Sulaimin, 2009). Berdasarkan penelitian sebelumnya, hipotesis yang ingin dikembangkan dalam penelitian ini adalah:

$\mathrm{H}_{2}$ : Manajemen Laba berpengaruh terhadap kinerja keuangan.

\section{Pengaruh Struktur Modal dan Kinerja Keuangan}

Menururt Van Horne dan Wachowiz (2007) struktur modal sebagai pendanaan permanen jangka panjang terdiri dari utang, saham preferen dan ekuitas saham biasa. Struktur modal merupakan komposisi utang dan ekuitas pada suatu perusahaan yang seringkali dihitung berdasarkan besaran relatif berbagai macam sumber pendanaan perusahaan. Sedangkan menurut Brigham dan Houston, struktur modal (capital structure) perusahaan merupakan gabungan dari modal sendiri (equity) dan utang perusahaan (debt). Modal sendiri berasal dari common stock, paid in capital, retained earning, dan dikurangi treasury stock (internal equity). Modal sendiri juga dapat berasal dari external equity yaitu apabila perusahaan menjual sebagian dari sahamnya kepada investor. Keputusan pendanaan perusahaan terkait dengan keputusan tentang komposisi dan bentuk sumber dana yang akan dipergunakan oleh perusahaan (Husnan \& Pudjiastuti, 2007).
Dalam praktiknya, manajer perusahaan bertugas mengidentifikasi struktur modal yang optimal dengan meminimalkan biaya keuangan perusahaan dan memaksimalkan laba (Zeitun \& Tian, 2007). Banyak sekali faktor yang dapat mempengaruhi struktur modal dan untuk menentukan struktur modal yang optimal bukanlah suatu ilmu yang pasti. Perusahaan yang berada dalam industri yang sama sekalipun seringkali memiliki struktur modal yang berbeda. Berbeda dengan perusahaan keuangan, khususnya bank, yang struktur modalnya diatur oleh Bank Indonesia, perusahaan non keuangan lebih fleksibel dalam penentuan komposisi struktur modalnya karena tidak terikat dengan peraturan seperti penyediaan modal minimum.

Sartono (2008) menyatakan bahwa terdapat dua kriteria dalam menentukan struktur modal yaitu meminimalkan Weighted Average Cost of Capital (WACC) dan memaksimalkan nilai perusahaan. Biaya modal rata-rata tertimbang (WACC) dapat diminimumkan apabila perusahaan menggunakan lebih banyak utang (Brigham \& Houston, 2006). Akan tetapi perlu diperhatikan juga bahwa penggunaan dana eksternal dapat menimbulkan risiko apabila perusahaan tidak dapat membayar utang-utangnya sehingga membuat likuiditas perusahaan terancam dan pada akhirnya mengancam posisi manajer (Yeniatie \& Destriana, 2010). Myers (2001) mengatakan bahwa struktur modal perusahaan berdasarkan pecking order theory terbentuk dari penggunaan pendanaan internal serta kebijakan dividen perusahaan. Pendanaan internal identik dengan profitabilitas perusahaan. Perusahaan dengan profitabilitas tinggi akan menggunakan dana internal yang berwujud laba ditahan, setelah itu baru akan menggunakan utang bila dirasa memang perlu untuk memenuhi keputusan pendanaan perusahaan. Kebijakan dividen perusahaan juga dapat mempengaruhi struktur modal ataupun sebaliknya, selain itu juga dapat menunjukan nilai perusahaan kepada 
pemegang saham atau shareholders (Murekefu \& Ouma, 1857). Dividend Payout Ratio merupakan bentuk kebijakan dividen perusahaan untuk menentukan jumlah laba ditahan serta memaksimalkan nilai perusahaan (Joni \& Lina, 2010).

Brigham dan Houston (2004) menyatakan bahwa struktur modal berpengaruh langsung terhadap kinerja keuangan. Begitupula dengan Calisir et al. (2010) yang menyatakan bahwa komposisi utang dan modal atau struktur modal memiliki pengaruh positif terhadap kinerja keuangan. Berdasarkan penelitian sebelumnya, hipotesis yang ingin dikembangkan dalam penelitian ini adalah:

$\mathrm{H}_{3}$ : Struktur modal berpengaruh terhadap kinerja keuangan.

\section{Metode Penelitian}

Populasi dalam penelitian ini adalah perusahaan manufaktur yang terdaftar di Bursa Efek Indonesia (BEI) sejak tahun 2011 sampai tahun 2013. Periode penelitian sejak tahun 2011 sampai dengan 2013 karena pada 23 Desember 2008 DSAK mengeluarkan pernyataan resmi bahwa IFRS mulai diterapkan secara bertahap. Penelitian ini meneliti perusahaan yang laporan keuangannya sudah menerapkan IFRS yaitu setelah tahun 2008. Sampel penelitian diambil dengan menggunakan metode purposive sampling. Adapun kriteria yang digunakan untuk penentuan sampel adalah:

1. Perusahaan manufaktur yang terdaftar di Bursa Efek Indonesia dari tahun 2011-2013.

2. Perusahaan yang memperoleh laba dari tahun 2011-2013.

3. Perusahaan menerbitkan laporan keuangan selama periode 2011-2013.

4. Perusahaan yang menerbitkan laporan keuangan dalam mata uang rupiah.

\section{Sumber Data dan Teknik Pengumpulan Data}

Sumber data yang digunakan dalam penelitian ini adalah data sekunder yaitu laporan keuangan tahunan (annual report) perusahaan yang tercatat di BEI tahun 2011-2013. Pengumpulan data dilakukan dengan teknik riset arsip (archival research), yaitu memeriksa dari referensi dan pengetahuan dari sumber-sumber sekunder yang telah tersedia yang kita kenal dengan sebutan historical document (Siagian, 2011). Data diperoleh dari website Indonesia Capital Market Directory (ICMD), website $\mathrm{BEI}$, website masing-masing perusahaan.

\section{Pengukuran Variabel \\ Kinerja Keuangan}

Kinerja keuangan merupakan variabel dependen dalam penelitian ini. Kinerja keuangan adalah suatu analisis yang dilakukan untuk melihat sejauh mana suatu perusahaan telah melaksanakan dan menggunakan sumber daya keuangan yang ada dengan baik dan benar. Pengendalian yang dilakukan oleh manajemen perusahaan dapat berupa penilaian kinerja atau prestasi seorang manajer dengan menilai atau membandingkan data keuangan perusahaan dalam periode berjalan. Ukuran yang sering digunakan untuk mengukur kinerja keuangan suatu perusahaan adalah rasio keuangan. Rasio keuangan yang digunakan dalam penelitian ini adalah ROA (Martono, 2007).

$$
\boldsymbol{R} \boldsymbol{O A}=\frac{\text { Laba Bersih Sebelum Pajak }}{\text { Total Aktiva }}
$$

\section{Konservatisme Akuntansi}

Konservatisme akuntansi dalam penelitian ini merupakan variabel independen. Pihak yang mendukung konservatisme menyatakan bahwa penerapan akuntansi konservatif akan menghasilkan laba yang berkualitas karena prinsip ini mencegah perusahaan untuk membesarbesarkan laba dan membantu pengguna laporan keuangan dengan menyajikan laba yang tidak overstated. Duellman (2006) menggunakan book to market ratio dikalikan dengan -1 untuk mengukur 
konservatisme. Ahmad (2007) menyatakan bahwa konservatisme menghasilkan nilai buku lebih kecil dibandingkan dengan harga pasar. Beaver dan Ryan (2010) juga mengukur konservatisme dengan menggunakan book to market ratio, perusahaan yang menerapkan konservatisme melaporkan net assets dan book to market ratio yang lebih rendah.

Book to Market Ratio $=\frac{\text { Book Value of Firm }}{\text { Market Value of Firm }}$

\section{Manajemen Laba}

Manajemen laba merupakan variabel independen dalam penelitian ini. Manajemen laba diukur dengan menggunakan modified Jones model untuk menghitung discretionary accruals. Model tersebut memisahkan discretionary accruals dan nondiscretionary accruals dan mengurangi asumsi bahwa komponen nondiscretionary accruals adalah konstan. Berdasarkan perspektif manajerial, akrual menunjukan instrumen-instrumen adanya manajemen laba. Perhitungan akrual yang tidak normal diawali dengan perhitungan akrual. Total akrual sebuah perusahaan dapat dipisahkan menjadi nondiscretionary accruals (tingkat akrual yang normal) dan discretionary accruals (tingkat akrual yang tidak normal). Tingkat akrual yang tidak normal ini merupakan tingkat akrual hasil rekayasa laba yang dilakukan oleh manajer (Dechow et al, 1995). Selengkapnya perhitungan manajemen laba adalah sebagai berikut:

$$
\mathrm{TAC}=\mathrm{Nit}-\mathrm{CFO} \text { it }
$$

Nilai total accrual (TA) yang diestimasi dengan persaman regresi OLS sebagai berikut:

$$
\begin{aligned}
\text { TAit/Ait-1 }= & \beta 1(1 / \text { Ait-1 })+\beta 2(\Delta \text { Revt } / \\
& \text { Ait- } 1)+\beta 3(\text { PPEt } / \text { Ait- } 1)+ \\
& \mathrm{e}
\end{aligned}
$$

Dengan menggunakan koefisien regresi diatas nilai non discretionary accruals (NDA) dapat dihitung dengan rumus:

NDAit $=\beta 1(1 /$ Ait- 1$)+\beta 2(\Delta$ Revit $/$ Ait$1-\Delta$ ARit/ Ait-1) $+\beta 3$ (PPEit / Ait-1)

Selanjutnya discretionary accrual (DA) dapat dihitung sebagai berikut:

$$
\text { DAit }=(\text { TAit } / \text { Ait-1 })-\text { NDAit }
$$

Keterangan :

DAit $=$ Discretionary Accruals perusahaan i pada periode ke $\mathrm{t}$

NDAit $=$ Non Discretionary Accruals perusahaan i pada periode ke $\mathrm{t}$

TAit $=$ Total akrual perusahaan $\mathrm{i}$ pada periode ke $\mathrm{t}$

Nit = Laba bersih perusahaan $\mathrm{i}$ pada periode ke- $t$

CFOit = Aliran kas dari aktivitas operasi perusahaan i pada periode ke $\mathrm{t}$

Ait-1 = Total aktiva perusahaan i pada periode ke $\mathrm{t}-1$

$\Delta$ Revt $=$ Perubahan pendapatan perusahaan i pada periode ke $\mathrm{t}$

PPEt = Aktiva tetap perusahaan pada periode ke $\mathrm{t}$

$\Delta$ Rect $=$ Perubahan piutang perusahaan $\mathrm{i}$ pada periode ke $t$

\section{Struktur Modal}

Struktur modal dalam penelitian ini merupakan variabel independen. Struktur modal merupakan komposisi utang dan ekuitas pada suatu perusahaan yang seringkali dihitung berdasarkan besaran relatif berbagai macam sumber pendanaan perusahaan. Struktur modal (capital structure) perusahaan merupakan gabungan dari modal sendiri (equity) dan utang perusahaan (debt). Keputusan pendanaan perusahaan terkait dengan keputusan tentang komposisi dan bentuk sumber dana yang akan dipergunakan oleh perusahaan (Husnan, 2007). Dalam praktiknya, manajer perusahaan bertugas mengidentifikasi struktur modal yang optimal dengan meminimalkan biaya 
keuangan perusahaan dan memaksimalkan laba (Zeitun, 2007). Dalam penelitian kali ini struktur modal diukur dengan menggunakan Debt to Equity Ratio (DER).

$$
\text { DER }=\frac{\text { Total Utang }}{\text { Total Ekuitas }}
$$

\section{METODE PENELITIAN}

\section{Metode Analisis Data}

Pengujian model pengaruh dan hubungan variabel bebas yang lebih dari dua variabel terhadap variabel dependen, menggunakan teknis analisis regresi linear berganda (multiple linear regression method) (Ghozali, 2006). Analisis regresi berganda ini meliputi uji parsial, uji simultan, dan koefisien determinasi (Nachrowi, 2006).

\section{Uji Asumsi Klasik}

\section{Uji Normalitas}

Pengujian normalitas digunakan untuk mengetahui sebaran dari error term dan memastikan bahwa error term terdistribusi secara normal. Variabel residual dinyatakan terdistribusi normal apabila nilai signifikansi KolmogorovSmirnov > 0,05. Jika data tidak terdistribusi secara normal, hal tersebut mengindikasikan bahwa data mengandung banyak outlier yang dapat diatasi dengan treatment seperti menghilangkan data outlier tersebut ataupun menggunakan logaritma natural dari setiap variabel (Lukas, 2010). Menurut Gujarati (2004) jika berhadapan dengan ukuran sampel yang kecil atau terbatas (data kurang dari 100 observasi), asumsi normalitas mempunyai peran yang kritis. Tetapi jika ukuran sampel cukup besar, kita dapat mengasumsikan bahwa asumsi normalitas telah terpenuhi.

\section{Uji Multikolinearitas}

Uji multikolinearitas bertujuan untuk menguji apakah dalam model regresi ditemukan adanya korelasi antar variabel bebas. Model regresi yang baik seharusnya menghindari adanya korelasi antar variabel independen (Ghozali, 2005). Salah satu cara untuk mendeteksi multikolinearitas dilakukan dengan menggunakan nilai
Variance Inflation Factor (VIF) dan tolerance. Kedua ukuran ini menunjukkan variabel independen manakah yang ditentukan oleh variabel independen lainnya. Jika nilai VIF $<10$ maka suatu model regresi terbebas dari asumsi multikolinearitas.

\section{Uji Autokorelasi}

Uji autokorelasi menunjukkan adanya kemungkinan terjadi korelasi antara anggota serangkaian data observasi yang diurutkan menurut waktu. Autokorelasi muncul karena observasi yang berurutan sepanjang waktu berkaitan satu sama lain. Model regresi yang baik adalah regresi yang bebas dari autokorelasi (Ghozali, 2005). Metode pengujian yang dapat dilakukan adalah dengan uji DurbinWatson (Uji DW).

\section{Uji Heteroskedastisitas}

Uji heteroskedastisitas bertujuan untuk mengetahui apakah dalam model regresi terjadi ketidaksamaan varian dari residual antara satu pengamatan ke pengamatan lainnya. Model regresi yang baik adalah tidak terjadi heteroskedastisitas. Gejala heteroskedastisitas dapat diuji dengan metode white test. Jika nilai probabilitas Obs*R-squared lebih besar dari $\alpha=0,05$, maka cukup untuk menyimpulkan bahwa tidak ada heteroskedastisitas dalam model (Nachrowi dan Usman, 2006)

\section{Uji Hipotesis}

Model yang digunakan dalam penelitian ini adalah metode regresi linier berganda. Analisis regresi linier berganda bertujuan untuk membuat perkiraan numerical atas suatu variabel dalam menggunakan lebih dari satu variabel independen. Berikut adalah persamaan regresi berganda untuk menguji hipotesis: 


$$
\mathbf{K K}=\alpha+\beta_{1} \mathrm{KA}+\beta_{2} \mathrm{ML}+\boldsymbol{\beta}_{3} \mathrm{SM}+\varepsilon
$$

Dimana:

$$
\begin{array}{ll}
\text { KK } & =\text { Kinerja Keuangan } \\
\beta_{1}-\beta_{5} & =\text { Koefisien Parameter } \\
\text { KA } & =\text { Konservatisme Akuntansi } \\
\text { ML } & =\text { Manajemen Laba } \\
\text { SM } & =\text { Struktur Modal } \\
\alpha & =\text { konstanta } \\
\varepsilon & =\text { error }
\end{array}
$$

\section{HASIL PENELITIAN DAN PEMBA- HASAN \\ Statistik Deskriptif}

Hasil analisis data pada penelitian ini menunjukkan bahwa terdapat beberapa outlier diantara sampel. Outlier adalah kasus atau data yang memiliki karakteristik unik yang terlihat berbeda jauh dari observasi-observasi lainnya dan muncul dalam bentuk nilai ekstrim baik untuk sebuah variabel tunggal atau variabel kombinasi (Riandini, 2014). Sebanyak 9 sampel dikeluarkan dari penelitian ini hingga pada akhirnya penelitian ini menggunakan 153 sampel. Statistik deskriptif untuk variabel-variabel yang digunakan dalam penelitian ini dijelaskan pada Tabel 1.

Berdasarkan Tabel 1, dapat dilihat bahwa jumlah sampel yang digunakan adalah sebesar 153 sampel. Tabel 1 menjelaskan mengenai deskripsi nilai minimum, maksimum, rata-rata, dan standar deviasi dari seluruh variabel yang diteliti.

\section{Hasil Uji Asumsi Klasik \\ Hasil Uji Normalitas}

Uji normalitas dilakukan untuk melihat apakah nilai residual terdistribusi dengan normal atau tidak. Uji normalitas diuji dengan menngunakan uji metode kolmogorov-smirnov untuk melihat normalitas data dengan angka yang lebih detail. Uji normalitas kedua yang dilakukan pada penelitian ini menggunakan metode onesample kolmogorov-smirnov test. Hasil uji kolmogorov-smirnov tersebut ditunjukkan pada Tabel 2.
Berdasarkan Tabel 2, nilai Asymp. Sig (2-tailed) menunjukkan nilai sebesar 0.317. Hasil yang didapatkan menjelaskan bahwa model regresi memenuhi asumsi normalitas karena nilainya lebih besar dari $\alpha=0.05$.

\section{Hasil Uji Multikolinearitas}

Terjadinya multikolinearitas dalam suatu penelitian dapat dilihat dari nilai TOL dan VIF yang terdapat pada masingmasing variabel independen. Suatu model regresi dinyatakan bebas dari multikolinearitas adalah jika memiliki nilai tolerance di bawah 1 dan nilai VIF di bawah 10. Berdasarkan Tabel 3 dapat kita lihat bahwa nilai tolerance ML $0.953<1$, KA $0.994<1$, SM $0.949<1$. Begitu pula dengan nilai VIF dari ML, KA, dan SM yaitu 1.050, 1.006, 1.053 yang ketiganya jauh berada di bawah 10. Jadi, dapat disimpulkan bawa tidak ada gejala multikolinearitas dalam model regresi yang digunakan.

\section{Uji Autokorelasi}

Uji autokorelasi merupakan uji yang dapat menunjukkan apakah variabel yang satu dengan yang lainnya memiliki kesinambungan. Penelitian ini menggunakan uji autokorelasi dengan metode pengujian Durbin-Watson. Hasil uji terhadap sampel dikatakan bebas dari autokorelasi apabila nilai $\mathrm{dW}>\mathrm{dU}$. Sesuai dengan pengujian, sampel yang digunakan berjumlah 153 selama 3 tahun menghasilkan dU: 1.7758. Dapat dilihat pada Tabel 4 bahwa besar dW adalah 1.788. Jadi dapat ditarik kesimpulan bahwa variabel bebas pada sampel dalam penelitian ini bebas dari autokorelasi.

\section{Hasil Uji Heteroskedastisitas}

Pengujian heteroskedastisitas pada penelitian ini dilakukan dengan menggunakan uji perhitungan spearman. Tabel 5 menunjukkan tidak adanya masalah heteroskedastisitas pada setiap variabel independen dimana hasil menunjukkan ML 
$0.167>0.05$, KA $0.695>0.05$, SM 0.370 $>0.05$.

\section{Uji Hipotesis}

\section{Hasil Uji F}

Uji statistik $F$ pada dasarnya menunjukkan apakah semua variabel bebas yang dimasukkan dalam model mempunyai pengaruh secara simultan terhadap variabel terikat atau dependen.

Berdasarkan hasil uji ANOVA atau $\mathrm{F}$ test pada Tabel 6, didapatkan $\mathrm{F}$ hitung sebesar 33.827 dengan tingkat probabilitas 0.000 (signifikan). Karena probabilitas jauh lebih kecil di bawah tingkat signifikansi 0.05 maka dapat disimpulkan bahwa variabel ML, KA, dan SM mempunyai pengaruh secara simultan terhadap variabel KK. Hasil dari uji F ini menjelaskan bahwa ketiga variabel bebas tersebut dapat dijadikan sebagai pengukur tingkat KK.

\section{Hasil Uji T}

Uji $\mathrm{t}$ bertujuan untuk menguji seberapa jauh pengaruh satu variabel independen secara individual yaitu Manajemen Laba (ML), Konservatisme Akuntansi (KA), dan Struktur Modal (SM) dalam menerangkan variabel dependen yaitu Kinerja Keuangan (KK). Uji t berada pada tingkat signifikansi 0.05 . Jika nilai probabilitas t lebih kecil dari 0.05 maka $\mathrm{H}_{1}$ diterima dan $\mathrm{H}_{0}$ ditolak. Hasil uji t dapat dilihat pada Tabel 7.

Konservatisme Akuntansi (KA) dalam penelitian ini terbukti memiliki pengaruh positif terhadap Kinerja Keuangan (KK). Hasil dari penelitian ini menunjukkan bahwa perusahaan yang menerapkan prinsip konservatisme akuntansi akan meningkatkan kinerja keuangan dari perusahaan tersebut. Hal ini membuktikan bahwa dengan menunda pengakuan laba dan mempercepat pengakuan beban, maka kualitas laporan keuangan yang dihasilkan oleh suatu perusahan akan baik, begitu pula dengan kinerja keuangannya.
Berdasarkan data yang telah diolah, dapat dibuktikan bahwa 42 perusahaan dari total 54 perusahaan manufaktur yang dianalisis melakukan konservatisme akuntansi dengan melihat nilai book to market ratio dari setiap perusahaan. Empat puluh dua perusahaan tersebut memiliki nilai book to market ratio yang lebih kecil dari rata-rata keseluruhan nilai book to market ratio yaitu 1.1573. Semakin rendah nilai book to market ratio yang dimiliki perusahaan berarti semakin konservatif pula perusahaan dalam mengakui pendapatan dan bebannya. Diterapkannya konservatisme akuntansi ini membuat laporan keuangan perusahaan pada periode berikutnya menghasilkan kinerja keuangan yang jauh lebih baik dari tahun sebelumnya. Hal tersebut dikarenakan beban diakui secepatnya walaupun kemungkinan terjadinya kecil, sedangkan pendapatan diakui apabila kasnya sudah diterima.

Hasil penelitian ini tidak sesuai dengan penelitian yang dilakukan oleh Yenti (2013) dimana hasil dari penelitian tersebut mendapati bahwa konservatisme akuntansi tidak menjamin penilaian ekuitas / kinerja keuangan yang tinggi. Hal ini menunjukkan bahwa ada faktor selain konservatisme akuntansi yang mempengaruhi penilaian ekuitas serta kinerja keuangan.

Sedangkan penelitian ini telah sesuai dengan penelitian sebelumnya yang dilakukan oleh Fala (2007) yang menyatakan bahwa penerapan konservatisme akuntansi akan menghasilkan laba serta kinerja keuangan yang berkualitas karena prinsip ini mencegah perusahaan untuk mengakui laba yang berlebihan sehingga laba yang dilaporkan tidak overstated. Penelitian ini juga sesuai dengan penelitian yang dilakukan oleh Feltham (1995) dan Watts (1993) yang membuktikan bahwa laba dan aktiva yang dihitung dengan akuntansi konservatif dapat meningkatkan kualitas laba sehingga dapat digunakan untuk menilai suatu perusahaan. 


\section{Manajemen Laba dan Kinerja Keua- ngan}

Manajemen Laba (ML) pada penelitian ini terbukti tidak berpengaruh terhadap variabel Kinerja Keuangan (KK). Hasil ini menolak hipotesis pertama yang menyatakan bahwa ML berpengaruh terhadap KK. ML pada penelitian ini dihitung dengan mengeluarkan non discretionary accruals dari total accruals yang ada pada perusahaan sampel sehingga diperoleh nilai discretionary accruals yang merupakan akrual tidak normal pada perusahaan sampel. Semakin besar suatu perusahaan melakukan manajemen laba maka nilainya akan terlihat pada discretionary accruals. Discretionary accruals dapat berupa negative ataupun positif tergantung pada jenis manajemen laba yang dilakukan oleh suatu perusahaan. Akrual yang memiliki nilai positif menunjukkan bahwa perusahaan melakukan manajemen laba dengan cara meningkatkan laba perusahaan pada periode berjalan, sedangkan akrual yang memiliki nilai negative menunjukkan bahwa perusahaan melakukan manajemen laba dengan cara menurunkan laba pada periode berjalan.

Dari data yang telah diolah dan diukur dengan menggunakan proksi discretionary accruals untuk menghitung estimasi akrual tidak normal yang dimiliki oleh suatu perusahaan pada suatu periode laporan keuangan, seluruh perusahaan yang berjumlah total 54 perusahaan pernah melakukan manajemen laba. Tetapi pada satu periode dari tiga periode laporan keuangan terdapat 8 perusahaan yang tidak menerapkan manajemen laba yaitu BUDI pada tahun 2013, ETWA pada tahun 2012, HMSP pada tahun 2013, KAEF pada tahun 2013, KBLI pada tahun 2011, SMSM pada tahun 2012, SRSN pada tahun 2013, UNVR pada tahun 2012. Manajemen laba yang dilakukan oleh setiap perusahaan bermacam-macam, ada yang positif dan ada juga yang negatif. Hal ini membuktikan bahwa manajemen laba yang dilakukan tergantung pada manajemen dan kebutuhan masing-masing perusahaan. Tetapi hasil dari data menunjukkan bahwa tren manajemen laba yang sering digunakan adalah income maximization atau peningkatan laba yaitu 40 perusahaan dari 54 perusahaan sampel. Hal ini membuktikan bahwa perusahaan pada umumnya menginginkan laba yang dilaporkan lebih tinggi, bisa untuk memperoleh bonus bagi manajemen, bisa untuk menstabilkan laba perusahaan dari tahun-ketahun, dan bisa juga untuk menarik perhatian investor.

Akan tetapi praktik manajemen laba yang diukur dengan menggunakan modified Jones Model dengan menghitung estimasi akrual suatu perusahaan terbukti tidak mempengaruhi kinerja keuangan perusahaan yang diukur dengan menggunakan rasio Return on Asset. Keadaan ini disebabkan oleh mulai diterapkannya IFRS secara bertahap pada tahun 2012. IFRS mewajibkan perusahaan untuk mengakui beban pada periode yang sama dimana pendapatan atas beban yang dikeluarkan tersebut diterima (matching principle). Hal ini menyebabkan laporan keuangan pada tahun 2012 dan 2013 cenderung memiliki nilai akrual tidak normal yang rendah dibandingkan dengan tahun 2011. Selain itu IFRS juga mewajibkan full disclosure dimana setiap perusahaan harus menerangkan secara detail keadaan-keadaan penting yang terkait dengan laporan keuangan pada periode tersebut. Oleh karena itu manajer atau pembuat laporan keuangan tidak dapat lagi membuat laporan keuangan dengan bebas sesuai dengan kondisi dan kebutuhannya.

Hasil dari penelitian ini tidak sesuai dengan penelitian yang dilakukan oleh Dharmasetya (2009) yang menyatakan bahwa manajemen perusahaan seringkali melakukan manajemen laba untuk menarik minat para investor karena menghasilkan laporan keuangan serta rasio kinerja keuangan yang baik. Penelitian ini juga tidak sesuai dengan penelitian yang 
dilakukan oleh DeFond (1994) dengan menggunakan model jones hasil penelitian yang didapat membuktikan bahwa pada suatu periode sebelum melanggar perjanjian kredit, perusahaan melakukan manipulasi akrual yang terbukti dengan nilai abnormal accrual pada periode tersebut positif dan signifikan.

Sedangkan hasil penelitian ini sesuai dengan penelitian yang dilakukan oleh Muid (2005) yang melakukan penelitian pada 32 perusahaan manufaktur terdaftar di Bursa Efek Jakarta dan mendapati bahwa tidak terdapat perbedaan antara perusahaan yang melakukan manajemen laba dengan yang tidak melakukan terhadap reaksi pasar serta kinerja keuangan. Hal ini memungkinkan terjadi dikarenakan tidak hanya komponen total accrual saja yang dapat mempengaruhi kinerja perusahaan tetapi juga terdapat faktor-faktor lain yang bisa menyebabkan kinerja perusahaan berbeda.

\section{Struktur Modal dan Kinerja Keuangan}

Variabel terakhir dalam penelitian ini adalah Struktur Modal (SM). SM yang diukur menggunakan Debt to Equity Ratio (DER) terbukti berpengaruh negatif terhadap Kinerja Keuangan (KK). Hal ini menunjukkan bahwa semakin besar suatu perusahaan memperoleh pendanaannya dari utang maka akan semakin rendah kinerja keuangan yang dihasilkan oleh perusahaan tersebut. Hal ini dikarenakan oleh beban bunga yang harus dibayar atas pendanaan dari utang memperkecil laba bersih yang diperoleh oleh suatu perusahaan.

Dari data yang telah diolah, terdapat 35 perusahaan dari total 54 perusahaan manufaktur yang diteliti menggunakan pendanaan yang lebih banyak berasal dari modal/ekuitas. Hal tersebut membuktikan bahwa kecenderungan perusahaan manufaktur lebih menyukai pendanaan dari segi modal, karena pembayaran deviden fluktuatif mengikuti laba/rugi perusahaan pada periode berjalan, tidak seperti apabila menggunakan pendanaan dengan utang yang harus membayar beban bunga sesuai dengan perjanjian utang yang ada. Selain dari segi beban, perusahaan yang memiliki banyak utang biasanya juga dihindari oleh investor karena memiliki kemungkinan gagal bayar yang tinggi. Hal-hal tersebutlah yang membuat perusahaanperusahaan manufaktur yang diteliti lebih menyukai pendanaan dari modal daripada utang.

Penelitian ini tidak sesuai dengan penelitian sebelumnya yang dilakukan oleh Brigham (2001) serta Calisir (2010) yang menyatakan bahwa komposisi utang dan modal / struktur modal memiliki pengaruh positif terhadap kinerja keuangan. Sedangkan penelitian ini sesuai dengan penelitian yang dilakukan oleh Bourseli (2001) dan Lin (2010) yang menemukan bahwa rasio utang terhadap jumlah aset berpengaruh negatif terhadap kinerja perusahaan.

Pertimbangan lain kenapa beberapa perusahaan menyukai pendanaan dengan menggunakan utang adalah karena beban bunga yang harus dibayar akan mengurangi beban pajak sehingga bisa terjadi penghematan. Brigham (1997) menyatakan bahwa beban bunga utang merupakan pengurang pajak yang dapat meningkatkan nilai perusahaan.

Tabel 1. Statistik Deskriptif Variabel Penelitian

\begin{tabular}{lrrrrr}
\hline & N & Minimum & Maximum & Mean & Std. Deviatior \\
\hline KK & 153 & 0.001 & 0.27 & 0.0871 & 0.06044 \\
\hline ML & 153 & -0.13 & 0.49 & 0.0599 & 0.08921 \\
\hline KA & 153 & -12.50 & -0.10 & -1.1573 & 1.58754 \\
\hline SM & 153 & 0.04 & 7.40 & 0.9885 & 1.00871 \\
\hline Valid N (listwise) & 153 & & & & \\
\hline
\end{tabular}


Tabel 2. One Sample Kolmogorov-Smirnov Test

\begin{tabular}{llr}
\hline & & Unstandardized Residual \\
\hline & & 153 \\
\hline & Mean & 0.000 \\
\hline & Std. Deviation & 0.04661883 \\
\hline & Absolute & 0.077 \\
\hline & Positive & 0.077 \\
\hline & Negative & -0.055 \\
\hline Test Statistics & & 0.959 \\
\hline Asymp. Sig. (2-tailed) & & $0.317^{\mathrm{c}, \mathrm{d}}$ \\
\hline
\end{tabular}

Tabel 3. Hasil Uji Multikolinearitas

\begin{tabular}{llll}
\hline Model & \multicolumn{3}{c}{ Collinearity Statistics } \\
\hline & & Tolerance & VIF \\
\hline 1 & (Constant) & & \\
\hline & ML & 0.953 & 1.050 \\
\hline & KA & 0.994 & 1.006 \\
\hline & SM & 0.949 & 1.053 \\
\hline
\end{tabular}

Tabel 4. Hasil Uji Autokorelasi

\begin{tabular}{lrrrrrr}
\hline Model & R & R Square & $\begin{array}{r}\text { Adjusted R } \\
\text { Square }\end{array}$ & $\begin{array}{l}\text { Std. Error of the Durbin-Watson } \\
\text { Estimate }\end{array}$ \\
\hline 1 & $0.637^{\mathrm{a}}$ & 0.405 & 0.393 & & 0.04709 & 1.788
\end{tabular}

Tabel 5. Hasil Uji Heteroskedastisitas Correlations

\begin{tabular}{rrrr}
\hline & & Absres \\
\hline Spearman's rho & ML & Corellation Coefficient & 0.112 \\
\hline & & Sig. (2-tailed) & 0.167 \\
\hline & $\mathrm{N}$ & 153 \\
\hline & CA & Correlation Coefficient & -0.032 \\
\hline & Sig. (2-tailed) & 0.695 \\
\hline & $\mathrm{N}$ & 153 \\
\hline & Correlation Coefficient & -0.073 \\
\hline & Sig. (2-tailed) & 0.370 \\
\hline & N & 153 \\
\hline & Correlation Coefficient & 1.000 \\
\hline & Sig. (2-tailed) & 153 \\
\hline
\end{tabular}

Tabel 6. Hasil Uji F

\begin{tabular}{llll}
\hline Model & & F & Sig \\
& & & \\
\hline 1 & Regression & 33.827 & 0.000 \\
\hline
\end{tabular}


Tabel 7. Hasil Uji T

\begin{tabular}{|c|c|c|c|c|c|}
\hline \multirow[t]{2}{*}{ Model } & \multicolumn{2}{|c|}{$\begin{array}{c}\text { Unstandardized } \\
\text { Residual }\end{array}$} & $\begin{array}{l}\text { Standardized } \\
\text { Coefficients }\end{array}$ & $\mathrm{t}$ & Sig. \\
\hline & B & Std. Error & Beta & & \\
\hline (Constant) & 0.130 & 0.006 & & 21.119 & 0.000 \\
\hline ML & 0.040 & 0.044 & 0.058 & 0.904 & 0.368 \\
\hline KA & 0.017 & 0.002 & 0.454 & 7.165 & 0.000 \\
\hline SM & -0.025 & 0.004 & -0.425 & -6.560 & 0.000 \\
\hline
\end{tabular}

\section{SIMPULAN，KETERBATASAN，DAN SARAN \\ Simpulan}

Berdasarkan pembahasan analisis data yang telah diuraikan, dapat diambil simpulan bahwa konservatisme akuntansi dalam penelitian ini diukur dengan book to market ratio dan terbukti berpengaruh positif terhadap kinerja keuangan. Sedangkan manajemen laba dalam penelitian ini diukur dengan discretionary accruals dan terbukti tidak berpengaruh terhadap kinerja keuangan. Namun, struktur modal dalam penelitian ini diukur dengan debt to equity ratio dan terbukti berpengaruh negatif terhadap kinerja keuangan.

\section{Keterbatasan}

Penerapan IFRS di Indonesia secara bertahap yang berarti bahwa tingkat penerapan IFRS di setiap perusahaan masih berbeda-beda. Maka belum ada data yang dapat menunjukkan secara pasti tingkat penerapan IFRS di tiap-tiap perusahaan. Selain itu, penyajian angka pada laporan keuangan tiap-tiap perusahaan yang diambil dari Bursa Efek Indonesia masih berbeda-beda sehingga mempersulit pengambilan data dan memungkinkan adanya human error.

\section{Saran}

Merujuk pada keterbatasan penelitian di atas dan literature terkait lainnya, maka beberapa saran bagi penelitian selanjutnya yaitu: melakukan penelitian lebih lanjut tentang pengaruh dari IFRS terhadap kinerja keuangan pada perusahaan di Indonesia pada saat penerapan IFRS sudah mulai terlihat dan dapat diukur penerapan IFRS pada setiap perusahaannya. Serta dapat melakukan uji beda untuk penelitian selanjutnya yang meneliti pengaruh IFRS terhadap kinerja keuangan dengan membandingkan tahuntahun dimana penerapan IFRS sudah dapat diukur dengan tahun-tahun sebelum diterapkannya IFRS sehingga bisa diperoleh kesimpulan yang jelas tentang hasil dari diterapkannya IFRS di Indonesia.

\section{DAFTAR PUSTAKA}

Ashbaugh, H., \& Pincus, M. (2001). Domestic accounting standards, international accounting standards, and the predictability of earnings. Journal of Accounting Research, 39(3), 417-434.

BAPEPAM-LK. (2010). BAPEPAM-LK Dukung Konvergensi PSAK ke IFRS. Diperoleh tanggal 31 Januari 2013 dari http://wartapedia.com/bisnis/korporasi/6006-bapepam-lkdukung-konvergensi-psak-keifrs.html

Basu, S. (1997). The conservatism principle and the asymmetric timeliness of earnings. Journal of Accounting \& Economics, 24(December): 3-37.

Brigham, E. F., \& Phillip, R. D. (2004). Intermediate Financial Management, Eight Edition. Thomson.

Choi, F. D. S., \& Meek, G. K. (2005). International Accounting 5th edition. NJ: Prentice Hall. 
Dharmasetya, L., \& Sulaimin, V. (2009). Merger dan Akuisisi tinjauan dari sudut Akuntansi dan Perpajakan. Jakarta: PT Elex Media Komputindo KOMPAS GRAMEDIA.

Enny \& Pudjiastuti. (2002). Dasar - Dasar Manajemen Keuangan. Yogyakarta: Unit Penerbitan dan Percetakan Akademi Manajemen Perusahaan YKPN.

Fala \& Dwiyana, A.S. (2007). Pengaruh Konservatisma Akuntansi Terhadap Penilaian Ekuitas Perusahaan Dimoderasi Oleh Good Corporate Governance. SNA $X$ :Ikatan Akuntan Indonesia.

Givoly \& Hayn, C. (2000). The changing time-series properties of earnings, cash fows and accruals: Has finanancial reporting become more conservative? Journal of Accounting and Economics, 29 (2000), 287-320.

Husnan \& Suad. (2003). Dasar-Dasar Teori Portofolio dan Analisis Sekuritas. Yogyakarta: BPFE-UGM.

IAS. (2011). Accounting Framework in Indonesia. Diperoleh tanggal 31 Januari 2013 darihttp://iasplus.com/ country.indonesi.htm\#0207

IFRS. (2011). International Financial Reporting Standards. London : IFRS Foundation Publication Department.

James, C., Horne, V., \& John, M. W. (2005). Prinsip-prinsip Manajemen Keuangan. Edisi ke duabelas. Jakarta: Salemba Empat.

Jensen, G. R., Donald, P. S., \& Thomas, S. Z. (1992) Simultaneous Determination of Insider Ownership, Debt, and Dividend Polices. Journal of Financial and Quantitative Analysis, 27(2).
Jermakowixz, E. K. (2004). Effects of Adoption of Internal Financial Reporting Standards in Belgium: The Evidence from BEL-20 Companies. Accounting in Europe, 1(1), 51-70.

Joni \& Lina. (2010). Faktor - Faktor Yang Mempengaruhi Struktur Modal. Jurnal Bisnis Dan Akuntansi, 12(2), 81-96.

Lafond, R., \& Rouchowdhury, S. (2007) Managerial Ownership and Accounting Conservatism. Available online at http:// www.ssrn.com

Lo \& Eko, W. (2005). Pengaruh Tingkat KesulitanKeuangan Perusahaan Terhadap Konservatisme Akuntansi. Simposium Nasional Akuntansi, VIII. Solo.

Martono \& Harjito, A. (2007). Manajemen Keuangan. Yogyakarta: Ekonisia-FE UII.

Mayangsari, S., \& Wilopo. (2002). Konservatisme Akuntansi, Value Relevance dan Discretionary Accruals: Implikasi Model FelthamOlhson (1996). Jurnal Riset Akuntansi Indonesia, September, 2002, 291-310.

Murekefu, T. M., \& Ochuodho, P. O. (2012). The Relationship Between Dividend Payout And Firm Performance: A Study Of Listed Companies In Kenya. European Scienticif Journal, 8(9).

Myers, S. C., \& Nicholas S. M. (1984). Corporate Financing and Investment Decisions When Firms Have Information That Investors Do Not Have. Journal ofFinance Economic, $13,187-221$. 
Nachrowi, D. N., \& Hardius, U. (2006). Pendekatan Populer dan Praktis Ekonometruka untuk Analisis Ekonomi dan Keuangan. Jakarta: Lembaga Penerbit Universitas Indonesia.

Natawidnyana. (2008). International Financial Reporting Standards: A Brief Description. Diperoleh tanggal 31 Januari 2013 dari http://natawidnyana.worpress.com/20 08/10/28/international-financialreporting-standards-ifrs-a-briefdescription/

Paek, W., Chen, L. H., \& Sami. H. (2007). Accounting Convervatism, earning Persistance and Pricing Multiples on Earning. Available online at http://www.ssrn.com

Resmi, S. (2002). Keterkaitan Kinerja Keuangan Perusahaan Dengan Return Saham. Kompak Nomor 6.

Sartono, R. A. (2000). Manajemen Keuangan. Yogyakarta: BPFEYogyakarta.

Soemarso, R. (2005). Akuntansi Suatu Pengantar. Jakarta: PT Rineka Citra.

Sulistyanto, H. S. (2008). Manajemen Laba: Teori dan Model Empiris. Jakarta: PT GramediaWidiasarana Indonesia

Suwardjono. (2005) Teori akuntansi, Perekayasaan Pelaporan Keuangan. Yogyakarta : BPFE.

Wardhani, R. (2008). Tingkat Konservatisme Akuntansi di Indonesia dan Hubungannya dengan Karekteristik Dewan sebagai Salah Satu mekanisme Corporate Governance. Hibah Penelitian Fakultas Ekonomi Universitas Indonesia.
Watt, L. R., \& Zimmerman, J. L. (1978). Toward a Positive Theory of the Determination of Accounting Standard. The Accounting Review, 53(1).

Watts, R. L. (2003). Conservatism in Accounting Part I: Explanations and Implications. WorkingPaper, Simon School of Business University of Rochester.

Winarni, F., \& Sugiarso, G. (2005). Manajemen keuangan. Yogyakarta: Media Pressindo.

Yeniatie \& Nicken, D. (2010). Faktor Faktor Yang Memengaruhi Kebijakan Hutang Pada Perusahaan Non Keuangan Yang Terdaftar Di Bursa Efek Indonesia. Jurnal Bisnis Dan Akuntansi, 12(1), 1-16.

Yenti, D. (2013). Pengaruh Motivasi, Komitmen Organisasi, Dan Partisipasi Penyusunan Anggaran Terhadap Kinerja Organisasi (Studi Pada SKPD Kota Padang). Jurnal Akuntansi, 1(1).

Zeitun, R., \& Tian, G. G. (2007). Capital Structure and Corporate Performance: Evidence from Jordan. Australasian Accounting Business and Finance Journal, 1(4). 